\title{
COMPARISON OF REAL WORLD LIPID PROFILE OF PATIENTS WITH TYPE 2 DIABETES AND GUIDELINE RECOMMENDATIONS
}

\author{
Mirac Vural Keskinler ${ }^{1}$, Irem Bozkurt ${ }^{1}$, Ozge Telci Caklili², Gunes Feyizoglu ${ }^{1}$, \\ Zeynep Gul ${ }^{1}$, Asli Karsli ${ }^{1}$ and Aytekin Oguz ${ }^{1}$ \\ ${ }^{1}$ Istanbul Medeniyet University Goztepe Training and Research Hospital, \\ Department of Internal Medicine, Istanbul, Turkey; \\ ${ }^{2}$ Istanbul University Faculty of Medicine, Department of Endocrinology and Metabolism, Istanbul, Turkey
}

\begin{abstract}
SUMMARY - Diabetes is a major risk factor for cardiovascular disease. Despite recommendations and available therapeutic options, patients with diabetes do not always reach the recommended lipid levels. In this study, our aim was to compare the real world lipid profile of type 2 diabetes patients with guideline recommendations for dyslipidemia. Four hundred and sixty eight consecutive patients referred to Outpatient Diabetes Clinic of Istanbul Medeniyet University were recruited. Patient anthropometric measurements (height, weight, waist circumference), biochemical test results (LDL cholesterol (LDL-c), triglycerides, HDL cholesterol, $\mathrm{HbA1c}$ ) and treatment modalities were recorded. $\mathrm{Pa}$ tients were stratified into cardiovascular risk categories according to the risk factors and their treatment dose was compared to the recommendations. Among 468 patients, 56 (12\%) patients had coronary heart disease (CHD). Thirty-four percent of these patients were not on statin treatment $(n=19)$ and their mean LDL-c level was $114 \pm 29 \mathrm{mg} / \mathrm{dL}(2.9 \pm 0.75 \mathrm{mmol} / \mathrm{L})$. Nineteen percent of these patients were on high intensity statin treatment (atorvastatin $40-80 \mathrm{mg}$, rosuvastatin $20 \mathrm{mg}$ ). Only four patients with CHD had LDL-c levels $<70 \mathrm{mg} / \mathrm{dL}(1.8 \mathrm{mmol} / \mathrm{L})$. Four hundred and twelve patients had no CHD. In these patients, the mean LDL-c level was $132 \pm 38 \mathrm{mg} / \mathrm{dL}(3.4 \pm 0.9 \mathrm{mmol} / \mathrm{L})$. Eighty $(19 \%)$ patients had LDL-c level lower than $100 \mathrm{mg} / \mathrm{dL}(2.5 \mathrm{mmol} / \mathrm{L})$. Overall $82 \%(\mathrm{n}=384)$ of the cohort had not achieved treatment goal. In conclusion, a more pronounced approach for statin treatment is needed in diabetes patients for both primary and secondary prevention of cardiovascular diseases.
\end{abstract}

Key words: Type 2 diabetes; Dyslipidemia; Coronary heart disease

\section{Introduction}

Cardiovascular diseases are the leading cause of death in the world ${ }^{1}$. Guidelines have been issued to decrease this rate and promote preventive cardiology ${ }^{2}$. Patients with atherosclerosis are at a higher risk compared to normal population and lowering lipid levels is essential for populations at risk.

Correspondence to: Ozge Telci Caklili, MD, Istanbul University Faculty of Medicine, Department of Endocrinology and Metabolism, Millet Street, 34493, Fatih, Istanbul, Turkey

E-mail: wattersonx@gmail.com

Received February 11, 2019, accepted April 10, 2019
Diabetes is a major risk factor of cardiovascular disease $^{3}$. It speeds atherosclerotic process and leads to ischemic heart disease. To lessen this atherosclerotic burden, the American Diabetes Association and European Society of Cardiology recommend LDL cholesterol (LDL-c) levels to be lowered to less than 100 $\mathrm{mg} / \mathrm{dL}(2.5 \mathrm{mmol} / \mathrm{L})$ in patients with diabetes ${ }^{4,5}$. Statins are available as lipid lowering drugs and their efficacy in diabetes is well studied ${ }^{6,7}$.

Despite recommendations and available therapeutic options, patients with atherosclerotic heart disease do not always have low lipid levels. EUROASPIRE study has shown that almost half of the patients with 
cardiovascular disease have higher LDL-c levels than recommended $^{8}$.

In this study, our aim was to compare real world lipid profile of patients with type 2 diabetes with guideline recommendations for hyperlipidemia.

\section{Material and Methods}

The study was conducted at Outpatient Diabetes Clinic of Istanbul Medeniyet University. Ethical approval was obtained from the Istanbul Medeniyet University Ethics Committee.

\section{Patients}

Four hundred and sixty eight consecutive patients referred to Outpatient Diabetes Clinic were recruited. Patient anthropometric measurements (height, weight, waist circumference), biochemical test results (LDL-c, triglycerides, HDL cholesterol (HDL-c), HbA1c) and treatment modalities were recorded. Patients were stratified into cardiovascular risk categories according to the risk factors and their treatment dose was compared to recommendations.

\section{Anthropometric measures}

Height was measured with a tape, weight with a digital scale, and waist circumference according to the NHANES III protocol by the same nurse ${ }^{8}$. After overnight fast, antecubital vein blood samples were collected into blood collection tubes including plain tubes without anticoagulant and tubes that contained EDTA. To obtain serum, the tubes were left to clot for 1 hour at the most and then centrifuged at $1500 \mathrm{~g}$ for $15 \mathrm{~min}$. Serum samples were analyzed without delay. Whole blood samples for HbA1c were collected into blood tubes containing EDTA.

Serum glucose, transaminases, cholesterol (total cholesterol and HDL-c) and triglyceride levels were measured by an Architect c 4000 analyzer (Abbott Laboratories, IL, USA). HbA1c levels were analyzed using high performance liquid chromatography (Primus U1tra2; Trinity Biotech USA Inc., NY, USA). LDL-c was estimated indirectly using Friedewald equation.

\section{Statistical analysis}

Statistical analyses were conducted with SPSS 21.0 (IBM Corp., Armonk, NY, USA). The normality of distribution of variables was assessed with ShapiroWilk and Kolmogorov-Smirnov tests. Subjects were compared for differences in two measurements using the paired samples t-test or Wilcoxon test. Correlations between variables were determined by Pearson correlation test or Spearman's rho. Data were expressed as mean \pm standard deviation. The level of statistical significance was set at $\mathrm{p}<0.05$ (two-tailed).

\section{Results}

Four hundred and sixty-eight patients (271 female and 197 male) were enrolled in the study. Their mean age was $58.1 \pm 10$ years. Demographic characteristics of the patients are reported in Table 1.

The mean LDL-c level of the patients was $129 \pm 38$ $\mathrm{mg} / \mathrm{dL}(3.3 \pm 0.9 \mathrm{mmol} / \mathrm{L})$. The mean LDL-c level in patients without statin treatment was $134.7 \pm 37 \mathrm{mg} /$ $\mathrm{dL}(3.4 \pm 0.9 \mathrm{mmol} / \mathrm{L})$. There were 20 (4\%) patients with LDL-c $<70 \mathrm{mg} / \mathrm{dL}(1.8 \mathrm{mmol} / \mathrm{L})$ and $105(22 \%)$ patients with LDL-c $<100 \mathrm{mg} / \mathrm{dL}(2.5 \mathrm{mmol} / \mathrm{L})$.

There were $56(12 \%)$ patients with coronary heart disease (CHD). Thirty four percent of these patients were not on statin treatment $(n=19)$ (Table 2) and their mean LDL-c level was $114 \pm 29 \mathrm{mg} / \mathrm{dL}(2.9 \pm 0.75$ $\mathrm{mmol} / \mathrm{L}$ ). Nineteen percent of these patients were on high intensity statin treatment (atorvastatin $40-80 \mathrm{mg}$, rosuvastatin $20 \mathrm{mg}$ ). Only four patients with CHD had LDL-c levels $<70 \mathrm{mg} / \mathrm{dL}(1.8 \mathrm{mmol} / \mathrm{L})$, which is the treatment goal for this patient population.

Four hundred and twelve patients had no CHD. Their mean LDL-c level was $132 \pm 38 \mathrm{mg} / \mathrm{dL}(3.4 \pm 0.9$ $\mathrm{mmol} / \mathrm{L}$ ) (Fig. 1). Sixty-seven patients were on statin treatment and $44 \%(n=30)$ had reached treatment goal. With or without treatment, 80 (19\%) patients had LDL-c level lower than $100 \mathrm{mg} / \mathrm{dL}(2.5 \mathrm{mmol} / \mathrm{L})$. Overall $82 \%(n=384)$ of the cohort had not achieved treatment goal.

There were 104 (22\%) patients on statin treatment. Eight (7\%) and 48 (44.4\%) patients had LDL-c levels $<70 \mathrm{mg} / \mathrm{dL}(1.8 \mathrm{mmol} / \mathrm{L})$ and $<100 \mathrm{mg} / \mathrm{dL}(2.5$ $\mathrm{mmol} / \mathrm{L}$ ), with the mean LDL levels of $65 \pm 2 \mathrm{mg} / \mathrm{dL}$ $(1.6 \pm 0.005 \mathrm{mmol} / \mathrm{L})$ and $80 \pm 10 \mathrm{mg} / \mathrm{dL} \quad(2 \pm 0.2$ $\mathrm{mmol} / \mathrm{L}$ ), respectively. Overall, $65 \%$ of the patients on statin treatment had not reached treatment goal.

Among patients on statin treatment, $8 \%(n=9)$ used high intensity treatment, whereas $92 \%(n=99)$ were on moderate intensity treatment. Forty nine percent $(n=53)$ 
Table 1. Demographic characteristics of the cohort

\begin{tabular}{|l|l|l|}
\hline Demographic characteristic & Mean & $\begin{array}{l}\text { Standard } \\
\text { deviation }\end{array}$ \\
\hline Age $(\mathrm{yrs})$ & 58.1752 & 10.2 \\
Height $(\mathrm{cm})$ & 163.1049 & 8.9 \\
Weight $(\mathrm{kg})$ & 83.1413 & 13.8 \\
Duration of diabetes (yrs) & 8.4209 & 6.6 \\
Glucose (g/dL) & 188.1028 & 83.5 \\
Creatinine (g/dL) & 1.0205 & 3.4 \\
Triglycerides (g/dL) & 179.4528 & 87.2 \\
$\begin{array}{l}\text { High-density lipoprotein } \\
\text { cholesterol (g/dL) }\end{array}$ & 43.0325 & 10.8 \\
$\begin{array}{l}\text { Low-density lipoprotein } \\
\text { cholesterol (g/dL) }\end{array}$ & 129.6966 & 38.8 \\
$\begin{array}{l}\text { Alanine aminotransferase } \\
\text { (g/dL) }\end{array}$ & 26.6681 & 27.0 \\
HbA1c $(\%)$ & 8.7465 & 2.2 \\
Body mass index (kg/m2) & 31.4815 & 5.1 \\
Total cholesterol (g/dL) & 209.7539 & 48.3 \\
\hline
\end{tabular}

Table 2. Rate of statin use according to coronary heart disease (CHD)

\begin{tabular}{|l|l|l|}
\hline Statin use & $\begin{array}{l}\text { With CHD } \\
\mathrm{n}=56\end{array}$ & $\begin{array}{l}\text { Without CHD } \\
\mathrm{n}=412\end{array}$ \\
\hline Using statin & $37(66 \%)$ & $67(16 \%)$ \\
Not using statin & $19(34 \%)$ & $345(87 \%)$ \\
\hline
\end{tabular}

of them were on atorvastatin $10 \mathrm{mg}, 27 \%(\mathrm{n}=29)$ on atorvastatin $20 \mathrm{mg}, 5.5 \%(\mathrm{n}=6)$ on atorvastatin $40 \mathrm{mg}$, $14.8 \%(\mathrm{n}=16)$ on rosuvastatin $10 \mathrm{mg}, 0.9 \%(\mathrm{n}=1)$ on rosuvastatin $20 \mathrm{mg}, 0.9 \%(\mathrm{n}=1)$ on rosuvastatin $40 \mathrm{mg}$, and $1.9 \%(\mathrm{n}=2)$ on both fibrate and statin treatment (atorvastatin $40 \mathrm{mg}$, rosuvastatin $10 \mathrm{mg}$ ).

The mean triglyceride level in study patients was $179 \pm 87 \mathrm{mg} / \mathrm{dL}(2.02 \pm 0.9 \mathrm{mmol} / \mathrm{L})$. Fourteen patients were only on fibrate treatment. In these patients, the mean triglyceride level was $206 \pm 90 \mathrm{mg} / \mathrm{dL}(2.3 \pm 1$ $\mathrm{mmol} / \mathrm{L})$.

According to ADA guidelines, $80 \%(n=375)$ of the patients aged $40-75$ should have received moderateintensive statin treatment; however, $82.4 \%(\mathrm{n}=309)$ of this population had received no treatment. ADA also recommends moderate-intensive statin therapy in patients aged $>75(n=20)$. In our cohort, 95\% $(n=19)$ had

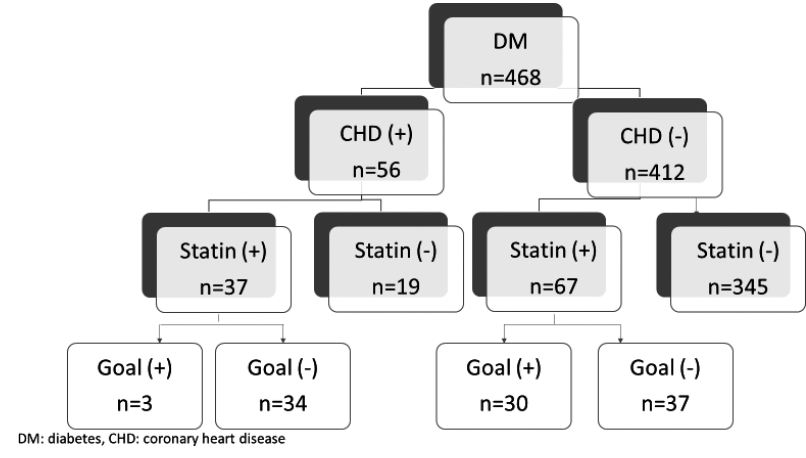

Fig. 1. Number of patients on statin therapy.

received no treatment and $5 \%(n=1)$ were on moderate statin treatment.

The mean HbA1c percent in patients using statin therapy was $8.2 \% \pm 2$, whereas in those without statin therapy it was $8.8 \% \pm 2$, yielding a statistically significant difference $(\mathrm{p}=0.01)$. There was no difference between the groups using statin and not using statin according to waist circumference, LDL-c levels, BMI, total cholesterol, fasting serum glucose, and age.

\section{Discussion}

The results of our study showed that they were far from achieving treatment goals for hyperlipidemia in patients with diabetes. Study results revealed that patients with diabetes did not use statin treatment as indicated, and patients with established CHD did not use statin for secondary prevention. The reasons for underachievement of treatment goals should be thoroughly examined.

Aside from the fact that patients with diabetes were not on recommended therapy for primary prevention, a more disturbing finding was that patients with both CHD and diabetes were not on recommended therapy. Ninety percent of CHD patients had not reached recommended LDL levels and $34 \%$ of them did not use statin at all. A worldwide analysis showed that statins were used in only $16.7 \%$ of patients for secondary prevention of $\mathrm{CHD}^{9}$. A large gap exists even between high-income countries and upper middle-income countries ( $70.9 \%$ vs. 20.1\%). Also, Mansur et al. report on the financial burden of statins as one of the main causes of the lack of adherence ${ }^{10}$; however, in Turkey, drug costs are covered by the government, therefore, it is an unlikely cause for nonadherence in this cohort. 
Patients sometimes abandon statin therapy due to side effects. Patients may have myalgia and rarely more serious effects can be observed, such as myopathy or rhabdomyolysis. In a meta-analysis with 46,262 subjects by Finegold et al., side effects attributed to statin treatment were minor and most of them were also seen with placebo ${ }^{11}$. Guidelines advocate that there is no need for creatinine kinase follow up in patients started on statin therapy ${ }^{5}$. It is only indicated in patients with symptoms.

Polypharmacy is a major concern in patients with diabetes. Patients without glycemic control often use both oral and injectable drugs. A study by Grant et al. reports that the mean number of drugs used by diabetes patients is $4^{12}$. Addition of another drug for prevention is not welcome by most of the patients. However, our analysis showed better glycemic control in patients on statin treatment. This finding may reflect the patient overall behavioral pattern related to his/her health care.

The AUDIT study has revealed that many physicians do not acknowledge diabetes as a cardiovascular risk factor ${ }^{13}$. Another physician related issue is that the recommended dose of statin often is not prescribed. Heintjes et al. showed the goal achievement rates to decrease without optimal therapy, and it was also affected by the statin therapy prescribed ${ }^{14}$. With pravastatin and simvastatin, lesser decrease is seen in hyperlipidemia compared to atorvastatin and rosuvastatin. ADA recommendation for patients of all ages with diabetes and atherosclerotic cardiovascular disease is that high-intensity statin therapy should be added to lifestyle therapy. In our study, only $19 \%$ of the patients were on recommended therapy.

There are doctors who advocate against statin use in patients with clear indications for treatment and media organizations prefer to interview these doctors for more attraction. Although scientific societies clearly explain the need for drug therapy in selected populations, these statements often are not heard enough. As a result, more and more people become reluctant to the initiation of statins and patient compliance decreases daily. Although nonadherence is a major problem for statin use, the use of other drugs such as hypertension medication is not optimal either ${ }^{15}$. There are single pills to increase adherence to hypertension and hyperlipidemia drugs and they are well tolerated ${ }^{16}$.

Limitations of the study include observational nature of the study. Also, patient history of statin use was not inquired, therefore we could not provide information regarding the causes of not using statins.

In conclusion, our study showed that a more pronounced approach for statin treatment is needed in patients with diabetes for both primary and secondary prevention of cardiovascular diseases. Along with patient education, physician centered educational courses are needed.

\section{References}

1. Forouzanfar MH, Afshin A, Alexander LT, Anderson HR, Bhutta ZA, Biryukov S, Cohen AJ. Global, regional, and national comparative risk assessment of 79 behavioural, environmental and occupational, and metabolic risks or clusters of risks, 1990-2015: a systematic analysis for the Global Burden of Disease Study 2015. Lancet. 2016;388(10053):1659-724, http://dx.doi.org/10.1016/S0140-6736(16)31679-8.

2. Bibbins-Domingo K, Grossman DC, Curry SJ, Davidson KW, Epling JW, García FA, Landefeld CS. Statin use for the primary prevention of cardiovascular disease in adults: US Preventive Services Task Force recommendation statement. JAMA. 2016;316(19):1997-2007, http://dx.doi.org/10.1001/ jama.2016.15450.

3. Paneni F, Costantino S, Cosentino F. Insulin resistance, diabetes, and cardiovascular risk. Curr Atheroscler Rep. 2014;16 (7):419, http://dx.doi.org/10.1007/s11883-014-0419-z

4. American Diabetes Association. Cardiovascular Disease and Risk Management: Standards of Medical Care in Diabetes 2018. Diabetes Care. 2018;41(Suppl 1):S86-S104. https://doi. org/10.2337/dc18-S009

5. Catapano AL, Graham I, De Backer G, Wiklund O, Chapman MJ, Drexel H, Reiner Ž. 2016 ESC/EAS Guidelines for the Management of Dyslipidaemias. Eur Heart J. 2016;37(39): 2999-3058. https://doi.org/10.1093/eurheartj/ehw272

6. Bellosta S, Ferri N, Arnaboldi L, Bernini F. Pleiotropic effects of statins in atherosclerosis and diabetes. Diabetes Care. 2000;23:B72.

7. Colhoun HM, Betteridge DJ, Durrington PN, Hitman GA, Neil HAW, Livingstone SJ, CARDS Investigators. Primary prevention of cardiovascular disease with atorvastatin in type 2 diabetes in the Collaborative Atorvastatin Diabetes Study (CARDS): multicentre randomised placebo-controlled trial. Lancet. 2004;364(9435):685-96. https://doi.org/10.1016/ S0140-6736(04)16895-5

8. Kotseva K, Wood D, De Backer G, De Bacquer D, Pyörälä K, Keil U, EUROASPIRE Study Group. Cardiovascular prevention guidelines in daily practice: a comparison of EUROASPIRE I, II, and III surveys in eight European countries. Lancet. 2009;373(9667): 929-40. https://doi.org/10.1016/ S0140-6736(09)60330-5

9. Yusuf S, Islam S, Chow CK, Rangarajan S, Dagenais G, Diaz $\mathrm{R}$, Kruger A. Use of secondary prevention drugs for cardiovas- 
cular disease in the community in high-income, middle-income, and low-income countries (the PURE Study): a prospective epidemiological survey. Lancet. 2011;378(9798):1231-43. https://doi.org/10.1016/S0140-6736(11)61215-4

10. Mansur AP, Mattar AP, Tsubo CE, Simão DT, Yoshi FR, Daci K. Prescription and adherence to statins of patients with coronary artery disease and hypercholesterolemia. Arq Bras Cardiol. 2001;76(2):115-8. http://dx.doi.org/10.1590/S0066782X2001000200002

11. Finegold JA, Manisty CH, Goldacre B, Barron AJ, Francis DP. What proportion of symptomatic side effects in patients taking statins are genuinely caused by the drug? Systematic review of randomized placebo-controlled trials to aid individual patient choice. Eur J Prev Cardiol. 2014;21(4):464-74. https://doi. org/10.1177/2047487314525531

12. Grant RW, Devita NG, Singer DE, Meigs JB. Polypharmacy and medication adherence in patients with type 2 diabetes. Diabetes Care. 2003 May;26(5):1408-12. https://doi.org/10. 2337/diacare.26.5.1408
13. Leiter LA, Betteridge DJ; AUDIT Investigators. The AUDIT Study: a worldwide survey of physicians' attitudes about diabetic dyslipidaemia. Diabetes. 2004;53 (Suppl 2):A285.https:// doi.org/10.1177/14746514060060010401

14. Heintjes EM, Beest FJ, Plat AW, Meerding WJ, Webb K, Sturkenboom MC, Herings R. Cholesterol level goal attainment with statins: clinical management guideline recommendations versus management in actual clinical practice. Pharmacotherapy. 2012;32(7):631-41. https://doi.org/10.1002/j.18759114.2011.01086.x

15. Mollaoglu M, Solmaz G, Mollaoglu M. Adherence to therapy and quality of life in hypertensive patients. Acta Clin Croat. 2015;54(4):438-43.

16. Naydenov Naydenov S, Margaritov Runev N, Ivanov Manov E, Georgieva Torbova-Gigova S. Efficacy and safety of a singlepill combination of atorvastatin/amlodipine in patients with arterial hypertension and dyslipidemia. Acta Clin Croat. 2018; 57(3):464-71. http://dx.doi.org/10.20471/acc.2018.57.03.09

Sažetak

\title{
USPOREDBA STVARNOG PROFILA LIPIDA U BOLESNIKA S DIJABETESOM TIP 2 I PREPORUKA IZ SMJERNICA
}

\author{
M. Vural Keskinler, I. Bozkurt, O. Telci Caklili, G. Feyizoglu, Z. Gul, A. Karsli i A. Oguz
}

Dijabetes je glavni čimbenik rizika za srčanožilne bolesti. Usprkos preporuka i dostupnih terapijskih mogućnosti bolesnici s dijabetesom ne postižu uvijek preporučene razine lipida. Cilj ovoga istraživanja bio je usporediti stvarni profil lipida u bolesnika s dijabetesom tip $2 \mathrm{~s}$ preporukama za dislipidemiju iz dotičnih smjernica. U istraživanje je bilo uključeno 468 uzastopnih bolesnika upućenih u Ambulantu za dijabetes Sveučilišta Medeniyet u Istanbulu. Bilježena su antropometrijska mjerenja (visina, težina, opseg struka), rezultati biokemijskih pretraga (LDL kolesterol, trigliceridi, HDL kolesterol, HbA1c) i načini liječenja. Bolesnici su podijeljeni u skupine kardiovaskularnog rizika prema rizičnim čimbenicima, a doze lijeka kojom su liječeni uspoređene su s preporukama. Među 468 bolesnika 56 (12\%) ih je imalo koronarnu srčanu bolest (KSB); $34 \%(\mathrm{n}=19)$ tih bolesnika nije primalo terapiju statinima, a njihova srednja razina LDL bila je $114 \pm 29 \mathrm{mg} / \mathrm{dL}(2,9 \pm 0,75$ $\mathrm{mmol} / \mathrm{L}$ ); $19 \%$ tih bolesnika primalo je visoko intenzivnu terapiju statinima (atorvastatin $40-80 \mathrm{mg}$, rosuvastatin $20 \mathrm{mg}$ ). Razine LDL $<70 \mathrm{mg} / \mathrm{dL}(1,8 \mathrm{mmol} / \mathrm{L})$ zabilježene su u samo četvero bolesnika s KSB. Četiristodvanaest bolesnika nije imalo KSB. U ovih bolesnika srednja razina LDL bila je $132 \pm 38 \mathrm{mg} / \mathrm{dL}(3,4 \pm 0,9 \mathrm{mmol} / \mathrm{L})$. Razine LDL niže od $100 \mathrm{mg} /$ dL (2,5 mmol/L) zabilježene su u 80 (19\%) bolesnika s LDL. Dakle, cilj liječenja sveukupno nije postignut u 82\% ( $\mathrm{n}=384)$ ispitivanih bolesnika. Zaključuje se kako je potreban snažniji pristup terapiji statinima u bolesnika s dijabetesom kako za primarnu tako i za sekundarnu prevenciju srčanožilnih bolesti.

Ključne riječi: Dijabetes tip 2; Dislipidemija; Koronarna srčana bolest 